\title{
Synthesis, Molecular Docking, and Evaluation of Some New Curcumin Analogs as Antimalarial Agents
}

\author{
Endang Astuti ${ }^{*}$, Tri Joko Raharjo ${ }^{1}$, Putra Makmur Boangmanalu ${ }^{1}$, Ilham Satria Raditya Putra ${ }^{1}$, \\ Stephanus Satria Wira Waskitha ${ }^{1}$, and Junita Solin ${ }^{2}$
}

${ }^{1}$ Department of Chemistry, Faculty of Mathematics and Natural Sciences, Universitas Gadjah Mada, Sekip Utara, Yogyakarta 55281, Indonesia

${ }^{2}$ Department of Agronomy, Faculty of Agriculture, Universitas Gadjah Mada, Jl. Flora, Yogyakarta 55821, Indonesia

\section{* Corresponding author:}

tel: $+62-8112809898$

email:endangastuti@ugm.ac.id

Received: July 7, 2020

Accepted: November 18, 2020

DOI: $10.22146 /$ ijc. 57646

\begin{abstract}
This research involves the synthesis, antimalarial evaluation, and molecular docking of several curcumin analogs. A total of six curcumin analog compounds were synthesized using aldol condensation using hydrochloric acid and sodium hydroxide catalysts. The synthesized compounds were elucidated using FTIR, ${ }^{1} \mathrm{H}-\mathrm{NMR},{ }^{13} \mathrm{C}-\mathrm{NMR}$, and LC-MS/MS. Subsequently, all curcumin analogs were tested as an antimalarial agent against Plasmodium falciparum 3D7 strain, and their mechanism of action was evaluated through a molecular docking study. Six curcumin analogs, i.e. 2,6-bis(2hydroxybenzylidene)cyclohexanone; 2,6-bis(2-hydroxybenzylidene)cyclopentanone; 1.5bis(2-hydroxyphenyl)penta-1,4-diene-3-one; 2,6-bis(3-hydroxybenzylidene)cyclo-hexanone; 2,6-bis(3-hydroxybenzylidene)cyclopentanone; and 1,5-bis(3-hydroxy-phenyl)penta-1,4diene-3-one have been successfully synthesized. In addition, 2,6-bis(2hydroxybenzylidene) cyclopentanone demonstrated the lowest $I C_{50}$ value and binding affinity of $0.04 \mu \mathrm{M}$ and $-7.6 \mathrm{kcal} / \mathrm{mol}$, respectively. Based on molecular docking studies, this compound also showed the most potent antimalarial activity targeted at PfATP6.
\end{abstract}

Keywords: curcumin analogs; antiplasmodium; aldol condensation; molecular docking

\section{- INTRODUCTION}

Malaria is a life-threatening disease caused by the plasmodium parasitic class and is transmitted through the bite of a female Anopheles mosquito. This infection spreads rapidly among people in the tropical region. Based on the World Health Organization (WHO) report in 2018, malaria has been identified as the leading cause of death worldwide (405,000 people). This prognosis has instigated the recommendation of antimalarial drugs for over 20 years, and resistance to the Plasmodium strain has recently been reported [1].

The incidence of antimalarial drug resistance is principally attributed to gene mutation and inappropriate or wrong dosage. This potentially provokes the mutation of transporter protein Plasmodium falciparum ( $P$. falciparum). Studies have shown a consequent effect on the entry pathway of artemisinin in the vacuole of parasitic cells [2-3]. These mutation conditions tend to influence the role of glycoprotein-p and further increases the drug export rate [4]. Therefore, identifying alternatives to the targeted protein is a plausible approach toward addressing antimalarial drug resistance.

Furthermore, curcumin is a polyphenol compound isolated from the rhizome of Curcuma longa, which has a tautomeric form, termed keto and enol. Curcumin generally has the properties shown in Table 1 . Ji and Shen (2009) conducted in vitro evaluation on the antiplasmodial activity of curcumin, and the results showed $\mathrm{IC}_{50}$ value within the range of 15-18 $\mu \mathrm{M}$ [5]. Also, the interaction with PfATP6 protein was further assessed through molecular docking. In addition, previous studies have shown the capacity for cyclopiazonic acid (CPA) to inhibit the calcium pump in PfATP6 protein due to the intrinsic molecular docking interaction residues on $\mathrm{Gln}^{56}$, $\mathrm{Leu}^{61}, \mathrm{Val}^{61}$, and $\mathrm{Asn}^{101}$ [6]. 
The experimental study showed an $\mathrm{IC}_{50}$ value of 1.15 and $2.45 \mu \mathrm{M}$ for the keto and enol forms, respectively. However, other reports have highlighted the poor bioavailability of curcumin in clinical applications [7-8].

The variation of $\alpha, \beta$-diketone group to monocarbonyl, as shown in Fig. 1, potentially improves curcumin stability and bioavailability [9]. This phenomenon is attributed to the transfer of oxygen electron pairs in the carbonyl group to generate a conjugation structure of unsaturated carbonyls under alkaline conditions $(\mathrm{pH}>$ 6.5) [10]. Therefore, it is necessary to identify the novel curcumin analogs with a tendency to enhance bioavailability. In addition, both benzyl substituents have similar activating hydroxyl units, symmetrically aligned with the analog curcumin structure. These subsequently require two steps to achieve the aldol condensation mechanism, followed by dehydration after the enolate is formed. The current research is aimed at successfully synthesizing six curcumin analogs using an aldol condensation reaction. Therefore, all synthesized compound was investigated for antimalarial activity against $P$. falciparum 3D7 strain and docked against PfATP6 to evaluate the intrinsic mechanism of action.

Table 1. Chemical and physical properties of curcumin

\begin{tabular}{ll}
\hline Chemical and physical properties & Curcumin \\
\hline Molecular formula & $\mathrm{C}_{21} \mathrm{H}_{20} \mathrm{O}_{6}$ \\
Molecular weight & $368.35 \mathrm{~g} / \mathrm{mol}$ \\
Melting point & $183{ }^{\circ} \mathrm{C}$ \\
Color & Yellow \\
Solubility in water & Low \\
Reaction under base & Bright color \\
Reaction under acid & Bright yellow color \\
\hline
\end{tabular}<smiles></smiles>

Fig 1. Simplification of the $\alpha, \beta$-diketone of curcumin to mono-carbonyl chemical structure

\section{- EXPERIMENTAL SECTION}

\section{Materials}

The reagents, including 2-hydroxybenzaldehyde, 3-hydroxybenzaldehyde, cyclohexanone, cyclopentanone, acetone, ethanol, tetrahydrofuran, and sodium hydroxide, were purchased from Merck in pro analysis specification. In addition, hydrochloric acid was purchased from Mallinckrodt, while the materials used in the antimalarial evaluation include RPMI-1640, serum-blood, RBC (Red Blood Cell), curcumin, dimethyl sulfoxide (DMSO), and three-dimensional structure of PfATP6 (PDB ID: 2OA0).

\section{Instrumentation}

Structure elucidation of curcumin analogs was carried out using FTIR spectrophotometer (with $\mathrm{KBr}$ pellet method), ${ }^{1} \mathrm{H}-\mathrm{NMR}$ (JEOL $500 \mathrm{MHz}$ ), ${ }^{13} \mathrm{C}-\mathrm{NMR}$ (JEOL $125 \mathrm{MHz}$ ) spectrometers. The deuterated solvents, i.e., $\mathrm{CD}_{3} \mathrm{OD}$ and DMSO-d6, were used for NMR measurement. Liquid Chromatography-Mass Spectrometry (LC-MS/MS) analysis was conducted using Water Xevo Q-Tof.

\section{Procedure}

\section{Synthesis of 2,6-bis(2-hydroxybenzylidene)cyclo hexanone (A)}

The synthesis process was performed using a modified Pana et al. (2014) method [11]. This involved dissolving 2-hydroxybenzaldehyde ( $4.2 \mathrm{~mL}, 0.04 \mathrm{~mol}$ ) in $5 \mathrm{~mL}$ of ethanol and mixing with cyclohexanone $(2.1 \mathrm{~mL}$, $0.02 \mathrm{~mol}$ ) before excess sodium hydroxide was added. Furthermore, the solution was then stirred for $24 \mathrm{~h}$ to attain a reddish precipitate, which was further diluted with distilled water and neutralized with hydrochloric acid. The yellow solid was then filtered and recrystallized with methanol/ethanol $(1: 2 \mathrm{v} / \mathrm{v})$, and a yield of $61 \%$ was obtained. This product possess the following characteristics ${ }^{1} \mathrm{H}-\mathrm{NMR}$ (DMSO-d6) $\delta$ (ppm): 1.71-1.62 $(\mathrm{m}, 2 \mathrm{H}), 2.81(\mathrm{t}, \mathrm{J}=6 \mathrm{~Hz}, 4 \mathrm{H}), 6.84(\mathrm{t}, \mathrm{J}=8 \mathrm{~Hz}, 2 \mathrm{H}), 6.90$ $(\mathrm{d}, \mathrm{J}=8 \mathrm{~Hz}, 2 \mathrm{H}), 7.20(\mathrm{t}, \mathrm{J}=8 \mathrm{~Hz}, 2 \mathrm{H}), 7.32(\mathrm{~d}, \mathrm{~J}=8 \mathrm{~Hz}$, 2H), 7.81 (s, 2H), 9.93 (s, 2H). ${ }^{13} \mathrm{C}-\mathrm{NMR}$ (DMSO-d6) $\delta$ (ppm): $23.4\left(\mathrm{CH}_{2}\right), 28.6\left(\mathrm{CH}_{2}\right), 116.0(\mathrm{CH}), 119.1(\mathrm{CH})$, $122.9(\mathrm{CH}), 130.5(\mathrm{CH}), 130.7(\mathrm{CH}), 132.1(\mathrm{CH}=\mathrm{C})$, 
$135.7(\mathrm{C}=\mathrm{CH}), 157.1(\mathrm{C}-\mathrm{OH}), 189.5(\mathrm{C}=\mathrm{O})$. LC-MS/MS: $[\mathrm{M}+\mathrm{H}]^{+}=307$.

\section{Synthesis of 2,6-bis(2-hydroxybenzylidene)cyclo pentanone (B)}

The synthesis of 2,6-bis(2-hydroxybenzylidene)cyclo pentanone involved similar procedures observed with analog A. This involved the mixture and stirring of 2hydroxybenzaldehyde $(2.1 \mathrm{~mL}, 0.04 \mathrm{~mol}), 5 \mathrm{~mL}$ ethanol, cyclopentanone $(1.77 \mathrm{~mL}, 0.02 \mathrm{~mol})$, and excess sodium hydroxide for $24 \mathrm{~h}$. Therefore, the precipitate generated was diluted with distilled water and neutralized with hydrochloric acid before filtering and recrystallizing with methanol/ethanol $(1: 2 \mathrm{v} / \mathrm{v})$. The orange solid yield was $88 \%$, and characterized by the following properties: ${ }^{1} \mathrm{H}$ NMR (DMSO-d6) $\delta(\mathrm{ppm}): 2.07(\mathrm{~s}, 4 \mathrm{H}), 6.88(\mathrm{t}, \mathrm{J}=8 \mathrm{~Hz}$, $2 \mathrm{H}), 6.97(\mathrm{t}, \mathrm{J}=8 \mathrm{~Hz}, 2 \mathrm{H}), 7.23(\mathrm{~m}, 2 \mathrm{H}), 7.53(\mathrm{dd}, \mathrm{J}=8$ and $2 \mathrm{~Hz}, 2 \mathrm{H}), 7.80(\mathrm{~s}, 2 \mathrm{H}), 10.21(\mathrm{~s}, 2 \mathrm{H}),{ }^{13} \mathrm{C}-\mathrm{NMR}$ (DMSO-d6) $\delta(\mathrm{ppm}): 26.6\left(\mathrm{CH}_{2}\right), 116.2(\mathrm{CH}), 119.6(\mathrm{CH})$, $122.9(\mathrm{CH}), 127.4(\mathrm{CH}), 130.1(\mathrm{CH}), 131.4(\mathrm{CH}=\mathrm{C}), 136.9$ (C-CH), $158.1 \quad(\mathrm{C}-\mathrm{OH}), 195.8$ (C=O). LC-MS/MS: $[\mathrm{M}+\mathrm{H}]^{+}=293$.

\section{Synthesis of 1,5-bis(2-hidroxyphenyl)penta-1,4-diene- 3-one (C)}

In addition, 1,5-bis(2-hydroxybenzylidene)penta1,4-diene-3-one was synthesized using similar procedure. This involved mixing and stirring 2-hydroxybenzaldehyde $(2.1 \mathrm{~mL}, 0.04 \mathrm{~mol})$, ethanol $(5 \mathrm{~mL})$, acetone $(1.48 \mathrm{~mL}$, $0.02 \mathrm{~mol})$, and excess sodium hydroxide for $24 \mathrm{~h}$. The precipitate was then diluted with distilled water and neutralized with hydrochloric acid before filtering and recrystallizing with methanol/ethanol $(1: 2 \mathrm{v} / \mathrm{v})$. The yellow solid yield was $58 \%$, and was characterized by the following properties: ${ }^{1} \mathrm{H}-\mathrm{NMR}\left(\mathrm{CD}_{3} \mathrm{OD}\right) \delta(\mathrm{ppm}): 4.46(\mathrm{~s}, 2 \mathrm{H}), 6.88$ $(\mathrm{d}, \mathrm{J}=8 \mathrm{~Hz}, 2 \mathrm{H}), 6.88(\mathrm{t}, \mathrm{J}=8 \mathrm{~Hz}, 2 \mathrm{H}), 7.24(\mathrm{t}, \mathrm{J}=8 \mathrm{~Hz}$, $2 \mathrm{H}), 7.30(\mathrm{~d}, \mathrm{~J}=8 \mathrm{~Hz}, 2 \mathrm{H}), 7.62(\mathrm{dd}, \mathrm{J}=8$ and $2 \mathrm{~Hz}, 2 \mathrm{H})$, $8.09(\mathrm{~d}, \mathrm{~J}=16 \mathrm{~Hz}, 2 \mathrm{H}) \cdot{ }^{13} \mathrm{C}-\mathrm{NMR}\left(\mathrm{CD}_{3} \mathrm{OD}\right) \delta(\mathrm{ppm}): 117.1$ $(\mathrm{CH}), 120.9(\mathrm{CH}), 123.1(\mathrm{CH}=\mathrm{CH}), 126.2(\mathrm{CH}), 130.0$ $(\mathrm{CH}), 133.0(\mathrm{CH}), 140.8(\mathrm{CH}=\mathrm{CH}), 158.7(\mathrm{C}-\mathrm{OH}), 192.7$ $(\mathrm{C}=\mathrm{O}) . \mathrm{LC}-\mathrm{MS} / \mathrm{MS}:[\mathrm{M}+\mathrm{H}]^{+}=267$.

\section{Synthesis of 2,6-bis(3-hidroxybenzylidene)cyclo hexanone (D)}

The synthesis of 2,6-bis(3-hydroxybenzylidene)cyclo hexanone was performed using the method reported by Persittamaia (2018) [12]. This involved mixing 3hydroxybenzaldehyde (1 g, $8.2 \mathrm{mmol})$ and cyclohexanone $(0.4 \mathrm{~mL}, 4.1 \mathrm{mmol})$ in $0.5 \mathrm{~mL}$ tetrahydrofuran, followed by the dropwise introduction of $1 \mathrm{~mL}$ hydrochloric acid. The reaction was then stirred at $20-50{ }^{\circ} \mathrm{C}$ for several hours to yield $79 \%$ Sorrel solid with the following properties: ${ }^{1} \mathrm{H}-\mathrm{NMR}$ (DMSO-d6) $\delta$ (ppm): 1.66-1.71 (m, $2 \mathrm{H}), 2.84-2.86(\mathrm{~m}, 4 \mathrm{H}), 6.82(\mathrm{~d}, \mathrm{~J}=7.5,2 \mathrm{H}), 6.91(\mathrm{~s}, 2 \mathrm{H})$, $6.94(\mathrm{~d}, \mathrm{~J}=7.5 \mathrm{~Hz}, 2 \mathrm{H}), 7.25(\mathrm{t}, \mathrm{J}=8 \mathrm{~Hz}, 2 \mathrm{H}), 7.54(\mathrm{~s}$, 2H), 9.62 (s, 2H). ${ }^{13} \mathrm{C}-\mathrm{NMR}$ (DMSO-d6) $\delta$ (ppm): 22.5 $\left(\mathrm{CH}_{2}\right), 28.0\left(\mathrm{CH}_{2}\right), 116.1(\mathrm{CH}), 116.9(\mathrm{CH}), 121.2(\mathrm{CH})$, $121.4(\mathrm{CH}), 129.6(\mathrm{CH}), 136.4(\mathrm{CH}=\mathrm{C}), 136.7(\mathrm{C}=\mathrm{CH})$, $157.4(\mathrm{C}-\mathrm{OH}), 189.0(\mathrm{C}=\mathrm{O})$. LC-MS/MS: $[\mathrm{M}+\mathrm{H}]^{+}=307$.

\section{Synthesis of 2,6-bis(3-hidroxybenzylidene)cyclo pentanone (E)}

The synthesis of 2,6-bis(3-hydroxybenzylidene) cyclopentanone involved a similar procedure as analog D. This required mixing 3-hydroxybenzaldehyde $(1 \mathrm{~g}$, $8.2 \mathrm{mmol})$ and cyclopentanone $(0.36 \mathrm{~mL}, 4.1 \mathrm{mmol})$ in $0.5 \mathrm{~mL}$ tetrahydrofuran, followed by the dropwise introduction of $1 \mathrm{~mL}$ hydrochloric acid. Therefore, 54\% yield of a light-yellow solid was produced, featuring the following characteristics: ${ }^{1} \mathrm{H}-\mathrm{NMR}$ (DMSO-d6) $\delta$ (ppm): 3.01 (s, 4H), 6.84 (d, J = 8 Hz, 2H), 7.07 (s, 2H), $7.10(\mathrm{~d}, \mathrm{~J}=7.5 \mathrm{~Hz}, 2 \mathrm{H}), 7.26(\mathrm{t}, \mathrm{J}=8 \mathrm{~Hz}, 2 \mathrm{H}), 7.34(\mathrm{~s}$, 2H), 9.66 (s, 2H). ${ }^{13} \mathrm{C}-\mathrm{NMR}$ (DMSO-d6) $\delta$ (ppm): 26.1 $\left(\mathrm{CH}_{2}\right), 116.4(\mathrm{CH}), 116.8(\mathrm{CH}), 122.1(\mathrm{CH}), 130.1(\mathrm{CH})$, $132.7(\mathrm{CH}), 136.5(\mathrm{C}=\mathrm{CH}), 137.7(\mathrm{CH}=\mathrm{C}), 157.5(\mathrm{C}-$ $\mathrm{OH}), 195.4(\mathrm{C}=\mathrm{O})$. LC-MS/MS: $[\mathrm{M}+\mathrm{H}]^{+}=293$.

\section{1,5-bis(3-hidroxyphenyl)penta-1,4-diene-3-one (F)}

In addition, 1,5-bis(3-hydroxybenzylidene)penta1,4-diene-3-one was synthesized using a similar procedure as analog $\mathrm{D}$. This involved mixing 3-hydroxy benzaldehyde $(1 \mathrm{~g}, 8.2 \mathrm{mmol})$ and acetone $(0.3 \mathrm{~mL}$, $4.1 \mathrm{mmol}$ ) in $0.5 \mathrm{~mL}$ tetrahydrofuran, followed by the dropwise introduction of $1 \mathrm{~mL}$ hydrochloric acid. Therefore, $65 \%$ yield of a brown solid was produced, with the following characteristic features: ${ }^{1} \mathrm{H}-\mathrm{NMR}$ (DMSO-d6) $\delta(\mathrm{ppm}): 6.85(\mathrm{~d}, \mathrm{~J}=8 \mathrm{~Hz}, 2 \mathrm{H}), 7.14(\mathrm{~s}, 2 \mathrm{H})$, $7.22(\mathrm{~d}, \mathrm{~J}=8 \mathrm{~Hz}, 2 \mathrm{H}), 7.36(\mathrm{~d}, \mathrm{~J}=7 \mathrm{~Hz}, 2 \mathrm{H}), 7.41(\mathrm{t}, \mathrm{J}=$ $8 \mathrm{~Hz}, 2 \mathrm{H}), 9.63$ (s, 2H), 9.93 (d, J = $7 \mathrm{~Hz}, 2 \mathrm{H}) .{ }^{13} \mathrm{C}-\mathrm{NMR}$ (DMSO-d6) $\delta$ (ppm): $114.7(\mathrm{CH}), 117.9(\mathrm{CH}), 119.8$ 
$(\mathrm{CH}), 125.6(\mathrm{CH}=\mathrm{CH}), 130.1(\mathrm{CH}), 136.1(\mathrm{CH}), 143.1$ $(\mathrm{CH}=\mathrm{CH}), 157.8(\mathrm{C}-\mathrm{OH}), 188.7(\mathrm{C}=\mathrm{O})$. LC-MS/MS: $[\mathrm{M}+\mathrm{H}]^{+}=267$.

\section{Antiplasmodium activity}

These products were assayed for antiplasmodium activity, based on Trager and Jansen (1976) [13] against $P$. falciparum 3D7 culture. The in vitro micro-technique method used was developed by Basco (2007) [14]. This required the preparation of 96-well assay plates, followed by the distribution of $5400 \mu \mathrm{L}$ RPMI, $1200 \mu \mathrm{L}$ serumblood, $104.62 \mu \mathrm{L} \mathrm{RBC}$, and $15.38 \mu \mathrm{L}$ parasites. In addition, the curcumin analogs were then prepared with the following concentrations $100.00 ; 50.00 ; 25.00 ; 12.50$; and $6.25 \mu \mathrm{g} / \mathrm{mL}$, and poured into the 96-well at three repetitions. Subsequently, the $P$. falciparum parasite culture obtained at a $7.6 \%$ schizont stage was synchronized and divided into each well of the pre-treated 96-well microtiter plate. Therefore, the entire unit was placed in a $5 \% \mathrm{CO}_{2}$ incubator at $37{ }^{\circ} \mathrm{C}$ for $72 \mathrm{~h}$, using a candle jar method. The number of schizonts counted by microscopy comprised at least 1000 normal red blood cells, while the inhibition percentage was determined as follows:

Inhibition $(\%)=\frac{\mathrm{A}-\mathrm{B}}{\mathrm{A}} \times 100 \%$

where $\mathrm{A}$ and $\mathrm{B}$ denote the parasitemia percentage of the negative control and the sample, respectively. Subsequently, statistical analysis was performed using
SPSS version 7 software, with significance tested at 0.05 level to calculate the $\mathrm{IC}_{50}$ value.

\section{Molecular docking}

The three-dimensional structure of curcumin analogs was optimized using Gaussian ${ }^{\oplus} 09 \mathrm{~W}$, with the semiempirical AM1 method [15]. In addition, the enzyme crystal arrangement of the PfATP6 receptor was downloaded from Protein Data Bank (PDB ID: 2OA0), while the ligand and receptor were prepared using Discovery Studio Visualizer and Autodock Tools [16]. The molecular docking process was performed using Autodock Vina by setting the exhaustiveness value to 160 , although polar hydrogen atoms were added to the receptor before this step. Furthermore, redocking was then carried out against native ligands to validate the molecular docking procedure and the RMSD value at $<$ $2.000 \AA[17]$.

\section{- RESULTS AND DISCUSSION}

\section{Synthesis of Curcumin Analogs}

The pharmacophore modification of curcumin involves the replacement of $\alpha, \beta$-diketone with monocarbonyl. This process featured the use of hydroxy group alongside electron-donating to generate some novel compounds, including the mono-carbonyl analogs [10], as presented in Fig. 2. In addition, the reaction was controlled by TLC, and all compounds were characterized

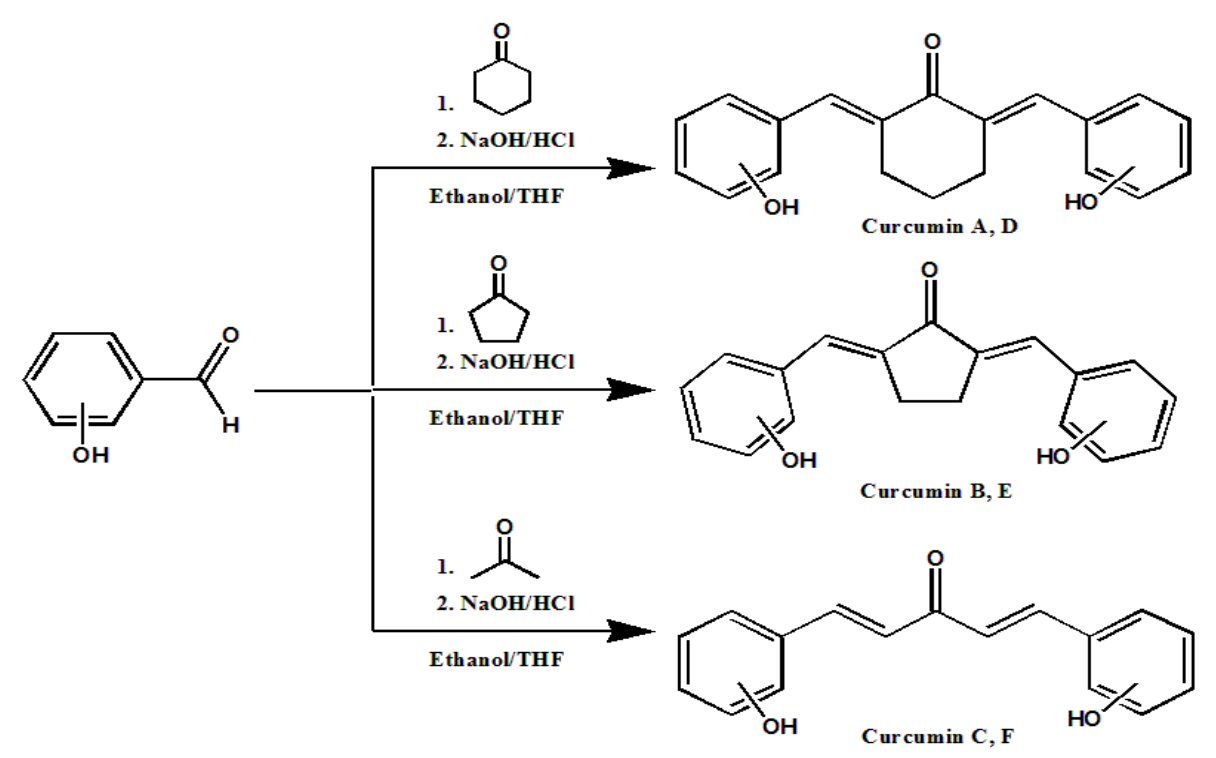

Fig 2. Scheme of synthesis of curcumin analog A-F 
using FTIR, ${ }^{1} \mathrm{H}-\mathrm{NMR},{ }^{13} \mathrm{C}-\mathrm{NMR}$, and LC-MS/MS spectrometers.

The results show a distinctive yellow color in each of the synthesized analogs, except for curcumin B (orange), D (Sorrel), and F (brownish). These discrepancies were possibly influenced by the stability and level of acidity while the compound is in the solid phase. Therefore, colors appearing more orange indicate higher alkalinity, while brown denotes acidity [11]. Fig. 3 shows the FTIR spectra from six synthesized curcumin analogs, which exhibit peaks of $3330,1574,1545$, and $1651 \mathrm{~cm}^{-1}$, representing the $\mathrm{OH}, \mathrm{C}=\mathrm{C}_{\text {aliphatic }}, \mathrm{C}=\mathrm{C}_{\text {aromatic, }}$ and $\mathrm{C}=\mathrm{O}$ stretching vibration frequencies, respectively. In addition, the $\mathrm{C}=\mathrm{O}$ stretching frequency typically appeared at $1715 \mathrm{~cm}^{-1}$ although the conjugation with $\mathrm{C}=\mathrm{C}$ double bond and the decline in two double-bonds characters instigate the reduction in values [11]. The mono-carbonyl and cyclic-groups of curcumin analog A, B, D, and E are possibly distinguished by the peaks present in regions 2931 and $2928 \mathrm{~cm}^{-1}$ for the $\mathrm{C}-\mathrm{H}$ stretching vibration frequencies. Also, another prominent successful feature was observed based on the peak correspondence to ortho-disubstituted (curcumin analog A, B, and C). This is one strong band in close proximity to $750 \mathrm{~cm}^{-1}$, which is easily distinguished from meta-disubstituted (curcumin analog $\mathrm{D}, \mathrm{E}$, and $\mathrm{F}$ ), and therefore indicates the presence of three medium bands between $690-880 \mathrm{~cm}^{-1}$.

The synthesized compounds were then analyzed using LC-MS/MS to obtain a more accurate quantitative and qualitative analysis. In addition, most of the products demonstrated a single peak on the LC chromatogram, indicating the high purity of the synthesized compound. The mass spectrometers also displayed the protonated peak mass of the molecular ion $\left([\mathrm{M}+\mathrm{H}]^{+}\right)$at $307(\mathrm{~A}$ and D), 293 (B and E), and 267 (C and F).

Furthermore, the structures were confirmed based on hydrogen splitting position on the ${ }^{1} \mathrm{H}-\mathrm{NMR}$ spectra in $\alpha, \beta$-unsaturated hydrogenated at the $\delta 7.0-7.5 \mathrm{ppm}$ region, which is more downfield than the usual range of $\delta$ 4.5-6.5 ppm [15]. This theoretically occurs due to electron delocalization in the $\alpha, \beta$-unsaturated system. Meanwhile, the proton attached to a hydroxyl group also

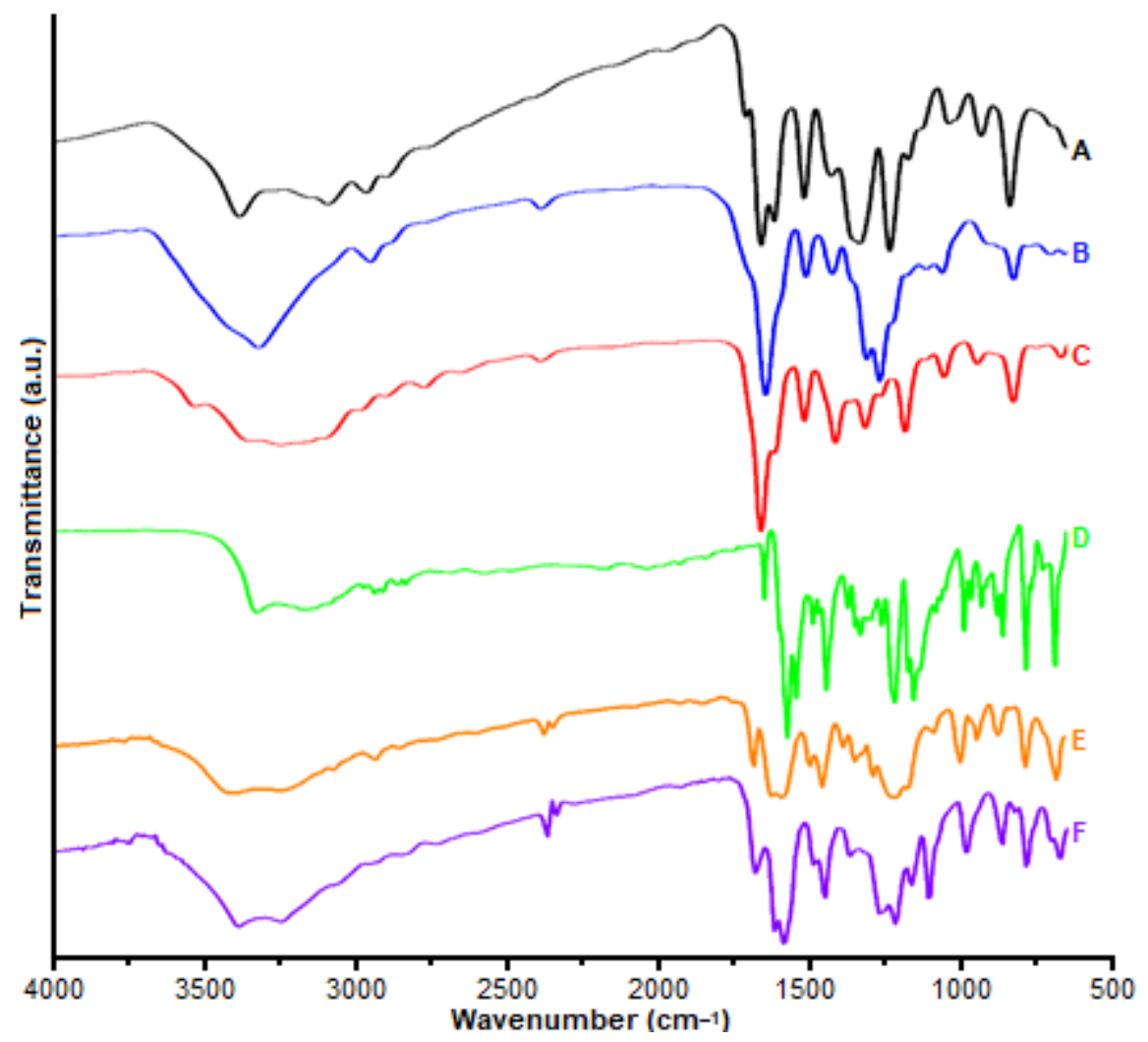

Fig 3. FTIR spectra of curcumin analogs A-F 
displays a peak at the deshielding region $\delta$ 9-10 ppm because of the oxygen lone pair attraction. The position 2hydroxy of curcumin analog A, B, and C possessed no splitting hydrogen, while 3-hydroxy has one between the hydroxyl and benzyl substituents with $\mathrm{D}(\delta 6.91 \mathrm{ppm}), \mathrm{E}$ $(\delta 7.07 \mathrm{ppm})$, and $\mathrm{F}(\delta 7.14 \mathrm{ppm})$. In addition, the number of carbons observed with the ${ }^{13} \mathrm{C}-\mathrm{NMR}$ spectra also corresponds to the curcumin analogs, comprising eleven peaks for $\mathrm{A}$ and $\mathrm{D}$, ten for $\mathrm{B}$ and $\mathrm{E}$, and nine for curcumin $\mathrm{C}$ and $\mathrm{F}$. These consist of $\mathrm{CH}_{2}$ aliphatic at $\delta 22-28 \mathrm{ppm}$ and $\mathrm{CH}$ aromatic $\delta 114-136 \mathrm{ppm}$. Moreover, splitting C$\mathrm{OH}$ for all products at the $\delta 157-158 \mathrm{ppm}$ range was more deshielded than the $\mathrm{CH}$ aromatics, due to the pair in electron atom $\mathrm{O}$. The $\mathrm{C}=\mathrm{CH}$ or $\mathrm{CH}=\mathrm{C}$ in cyclohexane and cyclopentane groups were observed at range $\delta$ 131-136 $\mathrm{ppm}$, while $\mathrm{CH}=\mathrm{CH}$ for penta-1,4-dien-3-one group was at $\delta 120-125 \mathrm{ppm}$ (near $\mathrm{C}=\mathrm{O}$ ) and $140-143 \mathrm{ppm}$ (near benzene). Finally, the signal for $\mathrm{C}=\mathrm{O}$ was marked at range $\delta$ 188-195 ppm.

\section{Antiplasmodium Activity}

Antiplasmodium assay was performed on cultured P. falciparum cells obtained at the blood-stage to determine the $\mathrm{IC}_{50}$ values. This treatment demonstrates the effect on schizont development in $\mathrm{RBC}$ and in medium RPMI-1640. In addition, the $\mathrm{IC}_{50}$ values of each curcumin analog (A-F) were divided into four categories, including promising $\left(\mathrm{IC}_{50}<1 \mu \mathrm{M}\right)$, active $\left(\mathrm{IC}_{50} 1-20 \mu \mathrm{M}\right)$, moderate $\left(\mathrm{IC}_{50} 20-100 \mu \mathrm{M}\right)$, and inactive $\left(\mathrm{IC}_{50}>100 \mu \mathrm{M}\right)$ [18]. The results tabulated in Table 2 showed the most potent activity against parasitic cells in compound $\mathrm{B}$ and $\mathrm{C}\left(\mathrm{IC}_{50}<1 \mu \mathrm{M}\right)$. Moreover, curcumin analog $\mathrm{A}$ and $\mathrm{D}$ were classified as moderate, while $\mathrm{E}$ and $\mathrm{F}$ demonstrated higher $\mathrm{IC}_{50}$. These products are considered active in interfering with cell inhibition and are comparable to curcumin, which is characterized by the ability to reduce parasitemia percentage by about $85-95 \%$.

\section{Molecular Docking}

The results of molecular docking are related to binding affinity and interaction between ligand on the active site of the calcium ATPase receptor, as shown in Table 3. The RMSD value of redocking was $0.801 \AA$, indicating a positive method validity with excellent resolution [17]. Furthermore, all products possessed a higher binding affinity than the CPA inhibitor, alongside good stability and adequate interaction with the active site. Table 3 showed the mediating role of $\mathrm{Leu}^{61}, \mathrm{Val}^{62}, \mathrm{Glu}^{309}, \mathrm{Asn}^{101}, \mathrm{Ala}^{102}$, and Leu ${ }^{311}$ amino acid residues during the bonding of CPA inhibitor with the active site [6]. Fig. 4 demonstrates the interaction between curcumin analog and any of the vital amino acids, as well as the potential to inhibit calcium ATPase in the absence of CPA inhibitors. This effect corresponds with one of the mechanisms to break the life cycle of parasites and the conforming $\mathrm{IC}_{50}$ value $[3,6]$.

Dohutia et al. (2017) reported the correlation between percentage inhibition of schizont and binding affinity using an in silico method. The presence of hydroxyl groups on the benzene ring potentially increases the interaction between the compounds produced and the active site by lowering the binding affinity with hydrogen bonding [19]. In addition, curcumin analog $\mathrm{A}$ is characterized by two hydrogen bonds $\left(\mathrm{Gln}^{56}, \mathrm{Asn}^{101}\right)$ and six van der Waals interactions $\left(\mathrm{Leu}^{98}, \mathrm{Pro}^{312}, \mathrm{Gln}^{25}, \mathrm{Lys}^{24}, \mathrm{Pro}^{308}\right.$, $\left.\mathrm{Leu}^{61}\right)$, and further yields $-8.3 \mathrm{kcal} / \mathrm{mol}$, while $\mathrm{B}$ has no hydrogen bond and seven van der Waals interaction $\left(\mathrm{Leu}^{98}, \mathrm{Asn}^{101}, \mathrm{Ile}^{307}, \mathrm{Leu}^{61}\right.$,

Table 2. The $\mathrm{IC}_{50}$ value of compound assayed

\begin{tabular}{clc}
\hline No. & \multicolumn{1}{c}{ Compound } & IC $_{50}$ value $(\mu \mathrm{M})$ \\
\hline 1 & 2,6-bis(2-hydroxybenzylidiene)cyclohexanone (A) & 11.53 \\
2 & 2,6-bis(2-hydroxybenzylidiene)cyclopentanone (B) & 0.04 \\
3 & 1,5-bis(2-hydroxyphenyl)penta-1,4-dien-3-one (C) & 0.63 \\
4 & 2,6-bis(3-hydroxybenzylidiene)cyclohexanone (D) & 16.93 \\
5 & 2,6-bis(3-hydroxybenzylidiene)cyclopentanone (E) & 31.88 \\
6 & 1,5-bis(3-hydroxyphenyl)penta-1,4-dien-3-one (F) & 39.04 \\
7 & Curcumin & 2.39 \\
\hline
\end{tabular}

Endang Astuti et al. 
Table 3. Interaction and binding affinity of CPA and curcumin analogs against PfATP6

\begin{tabular}{|c|c|c|}
\hline Compound & $\begin{array}{l}\text { Binding affinity } \\
(\mathrm{kcal} / \mathrm{mol})\end{array}$ & Interaction \\
\hline \multirow[t]{4}{*}{$\mathrm{CPA}^{*}$ (standard ligand) } & -10.0 & H-Bond: $\operatorname{Gln}^{56}$ \\
\hline & & Alkyl/ $\pi$-alkyl: $\operatorname{Pro}^{312}, \mathrm{Ile}^{307}, \mathrm{Val}^{62}, \mathrm{Leu}^{65}, \mathrm{Leu}^{253}, \mathrm{Leu}^{311}$ \\
\hline & & $\pi-\sigma:$ Leu $^{61}$ \\
\hline & & van der Waals: $\mathrm{Ala}^{102}, \mathrm{Asn}^{101}, \mathrm{Leu}^{98}, \mathrm{Glu}^{309}, \mathrm{Pro}^{308}, \mathrm{Phe}^{256}$ \\
\hline \multirow[t]{4}{*}{ A } & -8.3 & H-Bond: $\operatorname{Gln}^{56}$, Asn $^{101}$ \\
\hline & & Alkyl/ $\pi$-alkyl: Leu ${ }^{311}, \mathrm{Leu}^{25}, \mathrm{Pro}^{312}, \mathrm{Ile}^{315}$ \\
\hline & & $\pi-\sigma: \mathrm{Val}^{62}$ \\
\hline & & van der Waals: $\mathrm{Leu}^{98}, \mathrm{Pro}^{312}, \mathrm{Gln}^{25}, \mathrm{Lys}^{24}, \mathrm{Pro}^{308}, \mathrm{Leu}^{61}$ \\
\hline \multirow[t]{3}{*}{ B } & -7.6 & Alkyl/ $\pi$-alkyl: Leu ${ }^{253}, \mathrm{Pro}^{312}, \mathrm{Leu}^{311}, \mathrm{Leu}^{65}, \mathrm{Val}^{62}$ \\
\hline & & van der Waals: Leu $^{98}$, Asn $^{101}, \mathrm{Ile}^{307}, \mathrm{Leu}^{61}, \mathrm{Pro}^{308}, \mathrm{Ile}^{315}, \mathrm{Gln}^{250}$ \\
\hline & & Carbon H. bonding: Glü ${ }^{309}$ \\
\hline \multirow[t]{4}{*}{$\mathrm{C}$} & -8.5 & H-Bond: Lys ${ }^{252}$ \\
\hline & & $\pi$-stacked: $P h e^{834}$ \\
\hline & & $\pi$-alkyl: $\mathrm{Val}^{769}, \mathrm{Ile}^{829}, \mathrm{Leu}^{828}$ \\
\hline & & van der Waals: Leu $^{253}, \mathrm{Glu}^{255}, \mathrm{Phe}^{256}, \mathrm{Tyr}^{837}, \mathrm{Met}^{838}, \mathrm{Ile}^{765}, \mathrm{Ile}^{761}$ \\
\hline \multirow[t]{4}{*}{$\mathrm{D}$} & -8.4 & H-Bond: $\mathrm{Thr}^{316}, \mathrm{Val}^{104}$ \\
\hline & & Alkyl/ $\pi$-alkyl: Val ${ }^{62}, \operatorname{Pro}^{312}, \mathrm{Ile}^{315}, \mathrm{Leu}^{311}, \mathrm{Pro}^{308}$ \\
\hline & & $\pi-\sigma:$ Leu $^{61}$ \\
\hline & & van der Waals: $\mathrm{Gly}^{10}, \mathrm{Glu}^{10}, \mathrm{Asp}^{25}, \mathrm{Leu}^{253}, \mathrm{Gly}^{25}, \mathrm{Phe}^{256}, \mathrm{Ile}^{307}, \mathrm{Asn}^{101}, \mathrm{Gln}^{56}$ \\
\hline \multirow[t]{4}{*}{$\mathrm{E}$} & -7.8 & H-Bond: $\mathrm{Asp}^{254}, \mathrm{Asn}^{101}, \mathrm{Glu}^{309}$ \\
\hline & & $\pi$-alkyl: Val ${ }^{62}, \mathrm{Leu}^{65}, \mathrm{Ile}^{307}$ \\
\hline & & $\pi-\sigma: \operatorname{Leu}^{253}$ \\
\hline & & van der Waals: $\mathrm{Leu}^{98}, \mathrm{Pro}^{312}, \mathrm{Gln}^{25}, \mathrm{Lys}^{24}, \mathrm{Pro}^{308}, \mathrm{Leu}^{61}$ \\
\hline \multirow[t]{5}{*}{$\mathrm{F}$} & -8.1 & H-Bond: Lys ${ }^{252}$ \\
\hline & & $\pi$-alkyl: $\mathrm{Val}^{769}, \mathrm{Ile}^{828}$ \\
\hline & & $\pi-\sigma:$ Leu $^{828}$ \\
\hline & & $\pi$-stacked: Phe ${ }^{834}$ \\
\hline & & van der Waals: Met $^{83}$, Tyr $^{837}$, Ile $^{765}$, Ile $^{761}$, Leu $^{25}$, Phe $^{256}$ \\
\hline
\end{tabular}

$\left.\operatorname{Pro}^{308}, \mathrm{Ile}^{315}, \mathrm{Gln}^{250}\right)$, with a higher binding affinity value of $-7.6 \mathrm{kcal} / \mathrm{mol}$. Moreover, C possesses one hydrogen bond $\left(\mathrm{Lys}^{252}\right.$ ) and seven van der Waals interactions $\left(\mathrm{Leu}^{253}, \mathrm{Glu}^{255}, \mathrm{Phe}^{256}, \mathrm{Tyr}^{837}, \mathrm{Met}^{838}, \mathrm{Ile}^{765}, \mathrm{Ile}^{761}\right.$ ) alongside the best affinity of $-8.5 \mathrm{kcal} / \mathrm{mol}$, while $\mathrm{D}$ has two hydrogen bond $\left(\mathrm{Thr}^{316}, \mathrm{Val}^{104}\right)$ and nine van der Waals interaction $\left(\mathrm{Gly}^{10}, \mathrm{Glu}^{10}, \mathrm{Asp}^{25}\right.$, $\mathrm{Leu}^{253}, \mathrm{Gly}^{25}, \mathrm{Phe}^{256}, \mathrm{Ile}^{307}$, $\left.\mathrm{Asn}^{101}, \mathrm{Gln}^{56}\right)$, at $-8.4 \mathrm{kcal} / \mathrm{mol}$. The curcumin analog $\mathrm{E}$ features three hydrogen bond $\left(\mathrm{Asp}^{254}, \mathrm{Asn}^{101}, \mathrm{Glu}^{309}\right)$ and six van der Waals interaction $\left(\mathrm{Leu}^{98}, \mathrm{Pro}^{312}, \mathrm{Gln}^{25}, \mathrm{Lys}^{24}\right.$, $\mathrm{Pro}^{308}$, Leu ${ }^{61}$ ), while $\mathrm{F}$ possesses 1 possible hydrogen bond and six van der Waals interaction, accompanied by a binding affinity of $-7.8 \mathrm{kcal} / \mathrm{mol}$ and $-8.1 \mathrm{kcal} / \mathrm{mol}$, respectively. These properties indicate the possibility of determining binding affinity based on the ratio between a possible number of hydrogen bonds and van der Waals interaction [20]. Also, the similarity between the associations of synthesized compounds and the standard ligand are significant factors in the inhibitory properties. In addition, the hydrophobic relations with amino acid residues are also enhanced by the aromatic ring present in the transmembrane of PfATP6, which will stabilize the transmembrane helices [21]. This is evidenced by the interface of $\pi$-stacked with $\mathrm{Phe}^{834}$ and $\pi$ - $\sigma$ bonds with $\mathrm{Leu}^{61}, \mathrm{Val}^{62} \mathrm{Leu}^{253}$, and Leu ${ }^{828}$ residue observed in most target compound. 

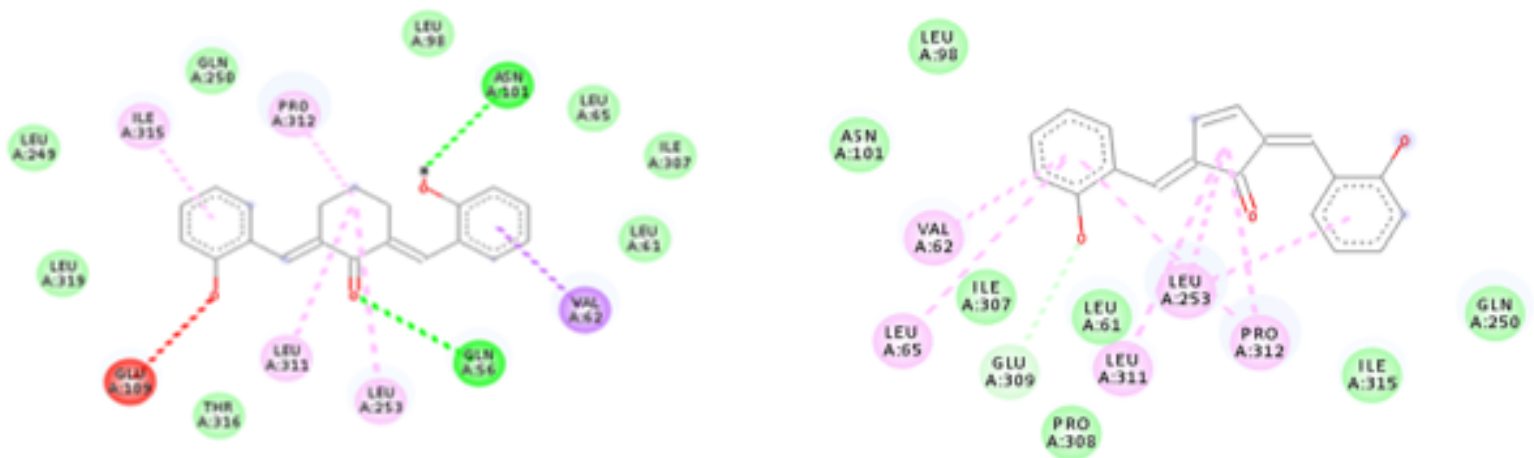

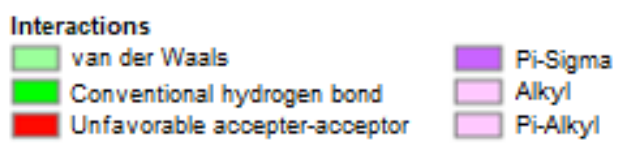

(A)

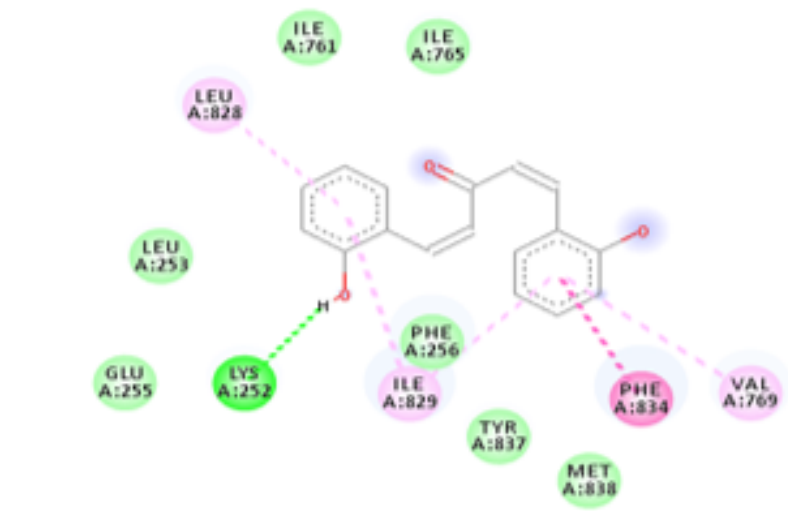

Interactions

$\square$ van der Waals
Conventional hydrogen bond $\square$ Pi-Pi stacked
Pi-Alkyl

(C)
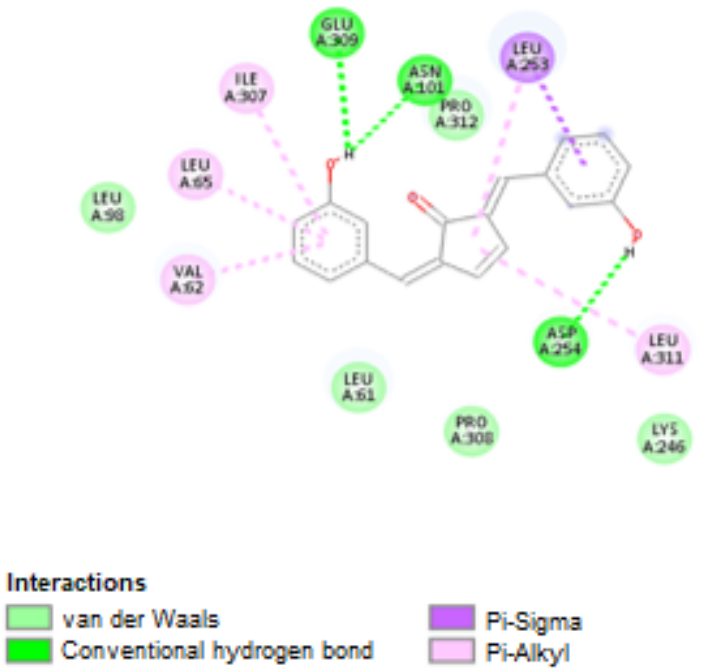

(E)

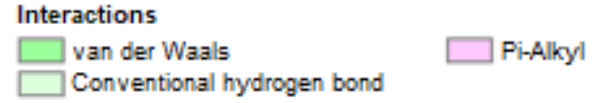

(B)

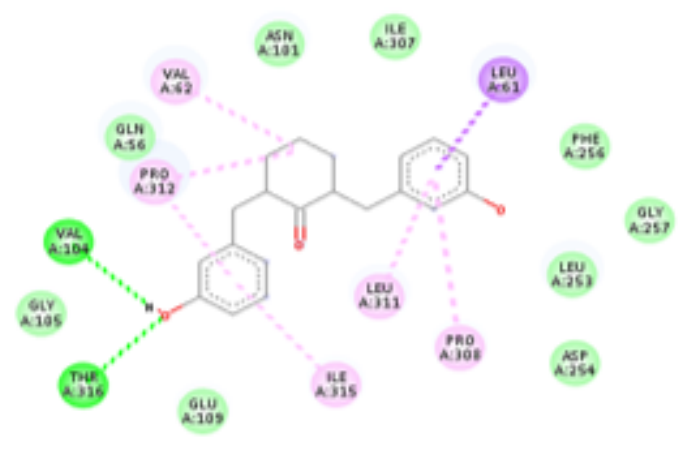

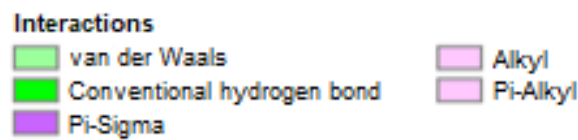

(D)

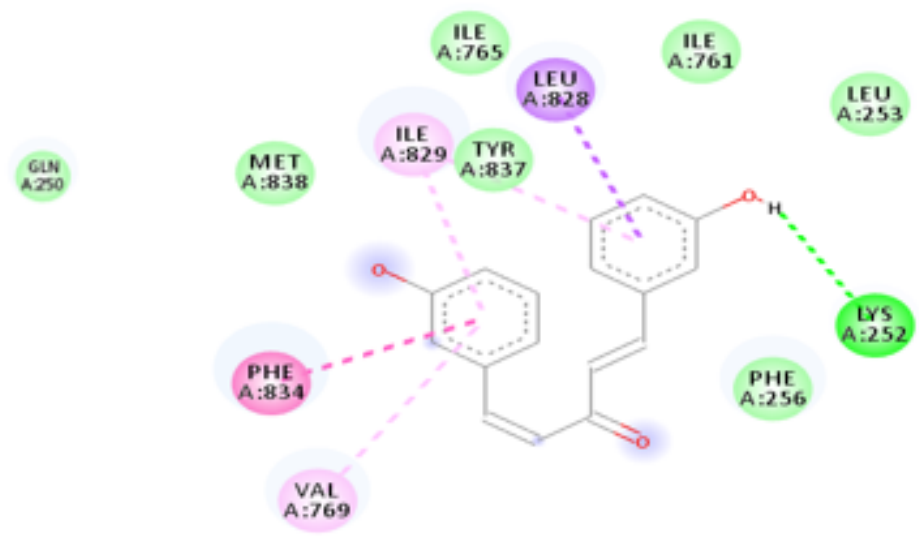

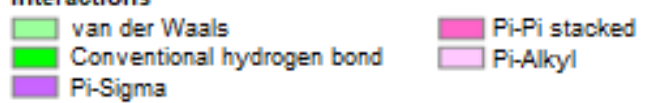

(F)

Fig 4. Visualization of molecular docking curcumin analog A-F toward the active site of PfATP6 protein 


\section{- CONCLUSION}

Based on the results and discussion, curcumin analogs of 2,6-bis(2-hidroxybenzylidene)cyclohexanone, 2,6-bis(2-hidroxybenzylidene)cyclopentanone, 1,5-bis(2hidroxyphenyl)penta-1,4-diene-3-one, 2,6-bis(3-hidroxy benzylidene)cyclohexanone, 2,6-bis(3-hidroxybenzylidene) cyclopentanone, and 1,5-bis(hidroxyphenyl)penta-1,4diene-3-one were successfully synthesized. The antimalarial activity of the yielded compounds was evaluated against $P$. falciparum 3D7 strain, and the effects demonstrated were good. In addition, the molecular docking result showed potential inhibitory characteristics in all curcumin analogs against PfATP6.

\section{- ACKNOWLEDGMENTS}

This work was financially funded by a research grant of Faculty Mathematics and Natural Sciences, Universitas Gadjah Mada.

\section{- AUTHOR CONTRIBUTIONS}

Endang Astuti, Tri Joko Raharjo, Putra Makmur Boangmanalu, Ilham Satria Raditya Putra conducted the experiment, Stephanus Satria Wira Waskitha performed the computation, Putra Makmur Boangmanalu, Ilham Satria Raditya Putra, Stephanus Satria Wira Waskitha wrote and revised the manuscript, Junita Solin and Tri Joko Raharjo translated and revised the manuscript. All authors agreed to the final version of this manuscript.

\section{- REFERENCES}

[1] Ministry of Health Republic of Indonesia, 2015, Indonesia Health Profile, Ministry of Health RI, Jakarta, Indonesia.

[2] Arnou, B., Montingny, C., Morth, J.P., Nissen, P., Jaxel, C., Møller, J.V., and le Maire, M., 2011, The Plasmodium falciparum $\mathrm{Ca}^{2+}$ ATPase PfATP6 Insensitive to artemisinin, but a potential drug target, Biochem. Soc. Trans., 39 (3), 823-831.

[3] Soni, R., Sharma, D., Rai, P., Sharma, B., and Bhatt, T.K., 2017, Signalling strategies of malaria parasite for its survival, proliferation, and infection during erythrocytic stage, Front. Immunol., 8, 349.
[4] Brochet, M., and Billker, O., 2016, Calcium signalling in malaria parasites, Mol. Microbiol., 100 (3), 397-408.

[5] Ji, H.F., and Shen, L., 2009, Interactions of curcumin with the PfATP6 model and the implications for its antimalarial mechanism, Bioorg. Med. Chem. Lett., 19 (9), 2453-2455.

[6] Moncoq, K., Trieber, C.A., and Young, H.S., 2007, The Molecular Basis for Cyclopiazonic Acid inhibition of the Sarcoplasmic Reticulum Calcium Pump, J. Biol. Chem., 282 (13), 9784-9757.

[7] Coma-Cros, E.M., Biosca, A., Lantero, E., Manca, M.L., Caddeo, C., Gutiérrez, L., Ramírez, M., Borgheti-Cardoso, L.N., Manconi, M., and Fernández-Busquets, X., 2018, Antimalarial activity of orally administered curcumin incorporated in Eudragit ${ }^{\oplus}$-containing liposomes, Int. J. Mol. Sci., 19 (5), 1361.

[8] Kim, Y.J., Lee, H.J., and Shin, Y., 2013, Optimization and validation of high-performance liquid chromatography method for individual curcuminoids in tumeric by heat-refluxed extraction, J. Agric. Food Chem., 61 (46), 1091110918.

[9] Manohar, S., Khan, S.I., Kandi, S.K., Raj, K., Sun, G., Yang, X., Molina, A.D.C., Ni, N., Wang, B., and Rawat, D.S., 2013, Synthesis antimalarial activity and cytotoxic potential of new monocarbonyl analogues of curcumin, Bioorg. Med. Chem. Lett., 23 (1), 112-116.

[10] Kumavat, S.D., Chaudhari, Y.S., Borole, P., Mishra, P., Shenghani, K., and Duvvuri, P., 2013, Degradation studies of curcumin, IJPRR, 3 (2), 5055.

[11] Pana, A.M., Badea, V., Bănică, R., Bora, A., Dudas, Z., Cseh, L., and Costisor, O., 2014, Network reaction of 2,6-bis(2-hydroxybenzylidene)cyclohexanone by external stimuli, J. Photochem. Photobiol., A, 283, 22-28.

[12] Persittamaia, I., 2018, Sintesis dan Uji Aktivitas Antibakteri Senyawa Analog Kurkumin 2,6-bis-(3'hidroksibenziliden)-sikloheksanon, Undergraduate 
Thesis, Faculty of Pharmacy, Universitas Gadjah Mada, Yogyakarta.

[13] Thomas, J.A., Collins, C.R., Das, S., Hackett, F., Graindorge, A., Bell, D., Deu, E., and Blackman, M.J., 2016, Development and application of a simple plaque assay for the human malaria parasite Plasmodium falciparum, PLoS One, 11 (6), e0157873.

[14] Basco, L.K., 2007, Field Application of in vitro Assays for the Sensitivity of Human Malaria Parasites to Antimalarial Drugs, World Health Organization, France.

[15] Pranowo, H.D., and Hetadi, A.K.R., 2011, Pengantar Kimia Komputasi, Lubuk Agung, Bandung, Indonesia.

[16] Forli, S., Huey, R., Pique, M.E., Sanner, M.F., Goodsell, D.S., and Olson, A.J., 2016, Computational protein-ligand docking and virtual drug screening with the AutoDock suite, Nat. Protoc., 11 (5), 905-919.

[17] Mena-Ulecia, K., Tiznado, W., and Caballero, J., 2015, Study of the differential activity of thrombin inhibitors using docking, QSAR, molecular dynamics, and MM-GBSA, PLOS One, 10 (11), e0142774.

[18] Kamaraj, C., Kaushik, N.K., Mohanakrishnan, D., Elango, G., Bagavan, A., Zahir, A.A., Rahuman, A.A., and Sahal, D., 2012, Antiplasmodial potential of medicinal plant extracts from Malaiyur and Javadhu hills of South India, Parasitol. Res., 111 (2), 703-715.

[19] Dohutia, C., Chetia, D., Gogoi, K., Bhattacharyya, D.R., and Sarma, K., 2017, Molecular docking, synthesis, and in vitro antimalarial evaluation of certain novel curcumin analogues, Braz. J. Pharm. Sci., 53 (4), e00084.

[20] Chen, D., Oezguen, N., Urvil, P., Ferguson, C., Dann, S.M., and Savidge, T.C., 2016, Regulation of protein-ligand binding affinity by hydrogen bond pairing, Sci. Adv., 2 (3), e1501240.

[21] Makwana, K.M., and Mahalakshmi, R., 2015, Implications of aromatic-aromatic interactions: From protein structures to peptide models, Protein Sci., 24 (12), 1920-1933. 